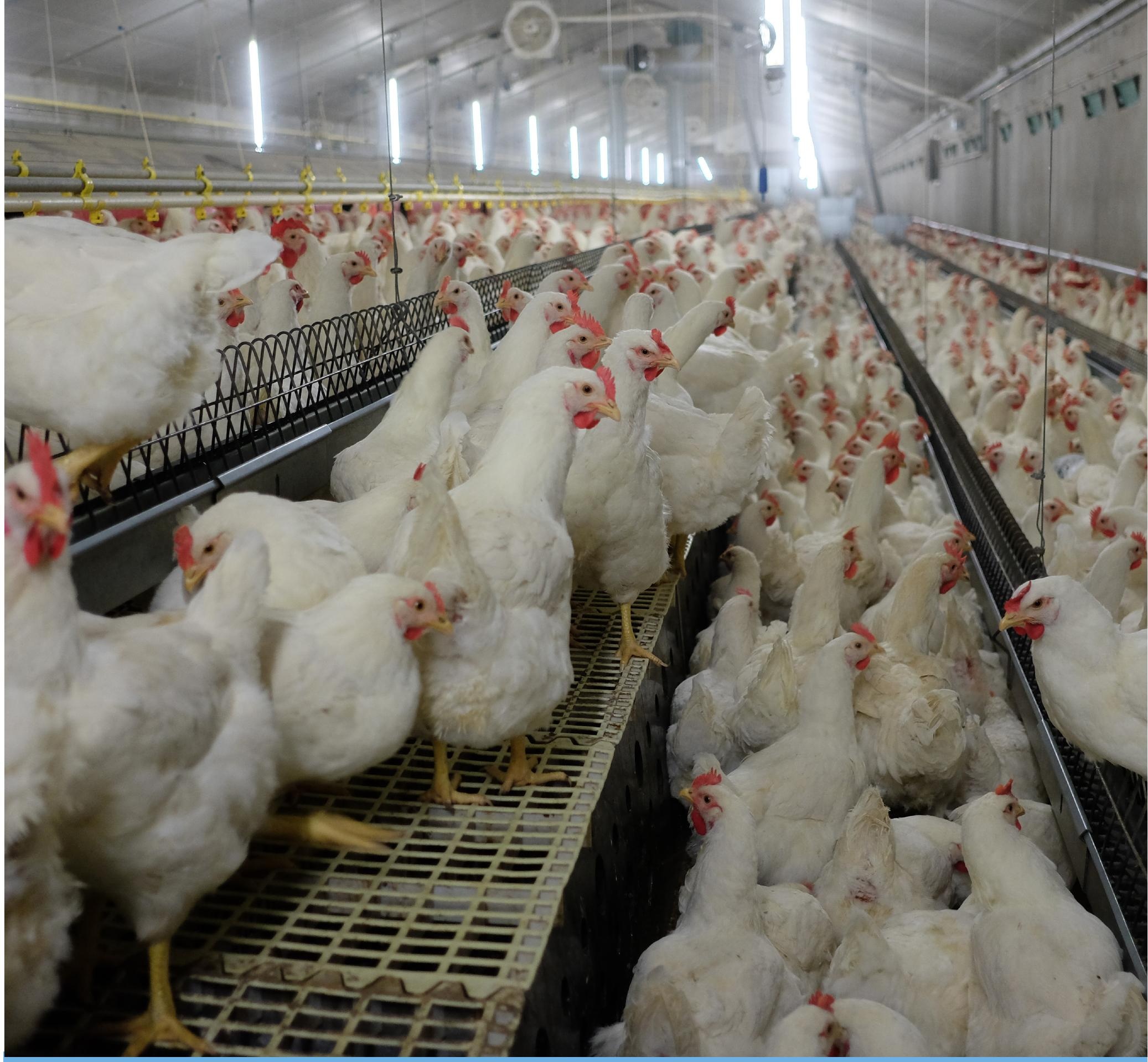

Voorkeur voor verhoogde rustplaats bij vleeskuikenouderdieren

OPENBAAR 



\section{Voorkeur voor verhoogde rustplaats bij vleeskuikenouderdieren}

Rick van Emous en Annemarie Mens

Dit onderzoek is uitgevoerd door Wageningen Livestock Research binnen het kader van de Publiek Private Samenwerking (PPS) "Breeders In Balance" (BIB) (BO-63-001-008). Dit project is een samenwerking tussen het Ministerie van Landbouw, Natuur en Voedselkwaliteit en een consortium van verschillende partijen. 
van Emous, R.A. en A.J.W. Mens, 2020. Voorkeur voor verhoogde rustplaats bij

vleeskuikenouderdieren. Wageningen Livestock Research, Rapport 1266.

In dit rapport worden de resultaten gepresenteerd van een studie naar de rustplaats preferentie van vleeskuikenouderdieren tijdens de legperiode, waarbij de dieren konden kiezen tussen roosters en zitstokken. Daarnaast konden de dieren op het strooisel, de drinklijn of in het legnest overnachten. Dit experiment is uitgevoerd in opdracht van het Consortium Breeders In Balance en het Ministerie van Landbouw, Natuur en Voedselkwaliteit. Uit de preferentietest met verschillende rustplaatsen blijkt dat ouderdieren een duidelijke voorkeur hebben voor een rooster in vergelijking met een zitstok om 's nachts op te rusten. Daarnaast verbleef een groot deel van de dieren door de tijd heen 's nachts consistent op hun geprefereerde rustplaats. De rustplaats blijkt ook invloed op het welzijn van de dieren te hebben. Bij de dieren op de zitstokken en drinklijn werden, t.o.v. het rooster meer en grotere borstblaren aangetroffen.

Dit rapport is gratis te downloaden op https://doi.org/10.18174/529579 of op

www.wur.nl/livestock-research (onder Wageningen Livestock Research publicaties).

(C) 2020 Wageningen Livestock Research

Postbus 338, 6700 AH Wageningen, T 03174839 53, E info.livestockresearch@wur.nl, www.wur.nl/livestock-research. Wageningen Livestock Research is onderdeel van Wageningen University \& Research.

\section{(cc) BY-NC}

Dit werk valt onder een Creative Commons Naamsvermelding-Niet Commercieel 4.0 Internationaallicentie.

(C) Wageningen Livestock Research, onderdeel van Stichting Wageningen Research, 2020 De gebruiker mag het werk kopiëren, verspreiden en doorgeven en afgeleide werken maken. Materiaal van derden waarvan in het werk gebruik is gemaakt en waarop intellectuele eigendomsrechten berusten, mogen niet zonder voorafgaande toestemming van derden gebruikt worden. De gebruiker dient bij het werk de door de maker of de licentiegever aangegeven naam te vermelden, maar niet zodanig dat de indruk gewekt wordt dat zij daarmee instemmen met het werk van de gebruiker of het gebruik van het werk. De gebruiker mag het werk niet voor commerciële doeleinden gebruiken.

Wageningen Livestock Research aanvaardt geen aansprakelijkheid voor eventuele schade voortvloeiend uit het gebruik van de resultaten van dit onderzoek of de toepassing van de adviezen.

Wageningen Livestock Research is NEN-EN-ISO 9001:2015 gecertificeerd.

Op al onze onderzoeksopdrachten zijn de Algemene Voorwaarden van de Animal Sciences Group van toepassing. Deze zijn gedeponeerd bij de Arrondissementsrechtbank Zwolle. 


\section{Inhoud}

$\begin{array}{ll}\text { Woord vooraf } & 5\end{array}$

$\begin{array}{ll}\text { Samenvatting } & 7\end{array}$

1

$\begin{array}{lr}\text { Inleiding } & 9\end{array}$

$\begin{array}{llr}2 & \text { Materiaal en methoden } & 11\end{array}$

$2.1 \quad$ Dieren en verzorging 11

2.2 Accommodatie 11

2.3 Proefopzet 11

2.4 Waarnemingen $\quad 12$

$\begin{array}{lll}2.5 & \text { Berekeningen en statistische analyse } & 13\end{array}$

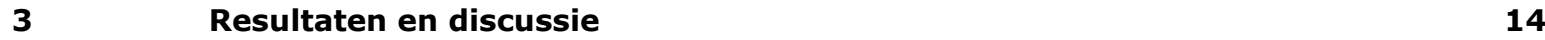

3.1 Verloop proef $\quad 14$

3.2 Gebruik verschillende rustplaatsen $\quad 14$

3.3 Gebruik rustplaats in de tijd van individuele dieren $\quad 15$

$\begin{array}{lll}3.4 & \text { Bevedering } & 17\end{array}$

$\begin{array}{lll}3.5 & \text { Prevalentie borstblaren } & 18\end{array}$

4

$\begin{array}{ll}\text { Conclusies } & \mathbf{2 1}\end{array}$

$\begin{array}{ll}\text { Literatuur } & 22\end{array}$

Bijlage 1 Indeling hokken in de voor- en experimentele periode 23

Bijlage 2 Verloop van het percentage dieren op of in de verschillende rustplaatsen (incl. voorperiode) 



\section{Woord vooraf}

Naar aanleiding van controles door de NVWA op praktijkbedrijven met vleeskuikenouderdieren bleek er onduidelijkheid omtrent de huisvestingsregels en de praktijksituatie. Met name het ontbreken van zitstokken in praktijkstallen werd opgemerkt. In de praktijk wordt tijdens de opfok- en legperiode gebruik gemaakt van respectievelijk springtafels (roosters) en een verhoogde roostervloer. Deze werden en worden door de sector gezien als een verhoogde rustplaats doordat roosters een verzameling zitstokken zijn. Tot nu toe is er echter nauwelijks objectief, vergelijkend onderzoek gedaan naar het gebruik van verschillende verhoogde rustplaatsen voor vleeskuikenouderdieren.

In dit rapport worden de resultaten gepresenteerd van een experiment met vleeskuikenouderdieren tijdens de legperiode, waarbij de dieren de keuze hadden tussen verhoogde rustplaatsen in de vorm van een rooster of zitstokken. Deze studie is uitgevoerd door Wageningen Livestock Research in opdracht van, en gefinancierd door het consortium 'Breeders In Balance' en het Ministerie van Landbouw, Natuur en Voedselkwaliteit. Het hier beschreven onderzoek kan bijdragen aan een oplossing in de discussie omtrent het toepassen van verhoogde rustplaatsen in stallen voor vleeskuikenouderdieren.

De auteurs bedanken de partners (Ministerie van LNV, PLUIMNED (Stuurgroep opfok en vermeerdering LTO/NOP en NVP), ABZ Diervoeding, Aviagen-EPI BV, Cobb Europe BV, De Heus Voeders BV, De Hoop Mengvoeders BV, Hubbard Nederland, Jansen Poultry Equipment, Kuikenbroederij Van Hulst BV, MSD Animal Health Nederland, PoultryPlus BV en Veterinair Centrum Someren) binnen het project Breeders In Balance voor de prettige samenwerking in het project.

Projectleider

Dr. ing. R.A. (Rick) van Emous 


\section{Samenvatting}

Uit onderzoek is bekend dat kippen de behoefte hebben aan een verhoogde rustplaats. In de eerste plaats wordt deze gebruikt om tijdens de nacht op te slapen, maar ook overdag maken kippen hier gebruik van. Overdag gebruiken ze deze voor verschillend soortspecifiek gedrag: om naar te vluchten, voor comfortgedrag en voor thermoregulatie. Met name het anti-predator gedrag heeft veel invloed op de behoefte om gedurende de nacht bescherming op hoogte te zoeken. Bij vleeskuikenouderdieren worden in de opfokperiode (meestal vanaf 6 weken leeftijd) doorgaans verhoogde rustplaatsen in de vorm van roosters aangeboden waarop water beschikbaar is. Hierdoor leren de dieren, als voorbereiding op de productieperiode, om omhoog te gaan en het legnest te ontdekken. Tijdens de legperiode hebben de ouderdieren de beschikking over 30 tot $65 \%$ roostervloer. Dit werd en wordt door de sector gezien als een goed alternatief voor zitstokken, omdat de roosters verhoogd zijn geïnstalleerd en een rooster als het ware een verzameling zitstokken is.

$\mathrm{Er}$ is nauwelijks onderzoek gedaan naar het gebruik van een verhoogde rustplaats bij vleeskuikenouderdieren. Samenvattend blijkt dat vleeskuikenouderdieren in de productieperiode tijdens vooral de donkerfase een voorkeur hebben tot een verhoogde rustplaats in vergelijking met het strooisel. Tijdens de donkerperiode lijkt er een voorkeur om te rusten op het hoogst mogelijke niveau. Het doel van het onderzoek in dit rapport beschreven was om te bepalen of vleeskuikenouderdieren, tijdens de productieperiode, een voorkeur vertonen voor een roostervloer of zitstokken als verhoogde rustplaats gedurende de nacht.

Het experiment werd uitgevoerd met vleeskuikenouderdieren tussen 40 en 60 weken leeftijd afkomstig vanuit een eerder experiment. Voor aanvang van het hier beschreven experiment vond selectie plaats van de aanwezige hennen. Het experiment startte met 26 hennen en 3 hanen per hok (Ross 308). De hennen en de hanen werden gerandomiseerd over de verschillende hokken om een neutrale aanvangssituatie te creëren. De vleeskuikenouderdieren werden gehuisvest in twee afdelingen van proefaccommodatie Carus te Wageningen. Beide afdelingen waren mechanisch geventileerd en bevatten 2 rijen met 6 hokken. In totaal werden 24 hokken gebruikt van 2,5 x 2,0 m.

De studie was opgezet als een preferentietest waarbij alle hokken precies hetzelfde waren ingericht met verschillende rustplaatsen. De dieren hadden de beschikking over twee verschillende rustplaatsen: hardhouten rooster $(150 \times 100 \mathrm{~cm}$ ) en 2 kunststof zitstokken (rechthoekig met afgeronde hoeken: totaal $4 \mathrm{~m}$ lengte). De zitstokken waren op dezelfde hoogte geïnstalleerd als het rooster $(50 \mathrm{~cm})$. Daarnaast hadden de dieren de beschikking over strooisel, drinklijn en legnest om te overnachten. Voor de experimentele periode ( $40 \mathrm{t} / \mathrm{m} 60$ weken leeftijd) hadden de dieren al de beschikking over zowel een rooster als zitstokken waardoor de dieren al gewend waren aan beide soorten rustplaatsen en ze geen voorkeur voor een van beiden hadden ontwikkeld.

Uit de preferentietest met verschillende rustplaatsen blijkt dat ouderdieren een duidelijke voorkeur hebben voor een rooster ( $51,5 \%$ van de dieren) in vergelijking met een zitstok (23,9\% van de dieren) om 's nachts op te rusten. Daarnaast werd bijna $80 \%$ van de dieren in meer dan $75 \%$ van de waarnemingen consistent op hun geprefereerde rustplaats waargenomen. Er werden meer en grotere borstblaren aangetroffen bij de dieren op de zitstokken (45,0\% van de hennen met gem. score 0,9$)$ en drinklijn $(81,7 \%$ van de hennen met gem. score van 1,9$)$ t.o.v. het rooster $(11,3 \%$ van de hennen met gem. score 0,2 ). 


\section{$1 \quad$ Inleiding}

Uit onderzoek is bekend dat kippen de behoefte hebben aan een verhoogde rustplaats. Gedurende de nacht wordt deze gebruikt om op te slapen, maar ook gedurende dag maken de kippen hier gebruik van, voor verschillend soortspecifiek gedrag: om naar te vluchten, voor comfortgedrag en voor thermoregulatie (Olsson and Keeling, 2000, 2002; Heikkilä et al., 2006; Wichman et al., 2007). In de nacht is voornamelijk het anti-predator gedrag (vluchten) een belangrijke aanleiding om op zoek te gaan naar bescherming (Wood-Gush et al., 1978; Newberry et al., 2001, Schrader en Müller, 2009). Uit onderzoek bij leghennen van Schrader en Müller (2009) bleek dat tijdens de legperiode meer dan $80 \%$ van de leghennen gebruik maakte van een verhoogde rustplaats. Uit hetzelfde onderzoek bleek ook dat het ontwerp (platform of stok) van de verhoogde rustplaats geen effect had, maar dat de hoogte bepalend is voor het gebruik van de plaats. Het merendeel (circa $80 \%$ ) maakte gebruik van de hoogste rustplaats. Verder is bij leghennen gebleken dat gedurende de dag de rang-lagere dieren meer gebruik maken van verhoogde rustplaatsen en dat de rang-hogere dieren hier meer gebruik van maken tijdens de nacht (Cordiner en Savory, 2001).

Een verhoogde rustplaats heeft tijdens de opfokperiode nog een extra functie: de dieren worden getraind om de verticale ruimte van het systeem te benutten, waardoor minder grondeieren worden gelegd (Brake, 1987). Om deze reden, en vanwege de positieve effecten op het welzijn, worden in de opfokperiode vanaf circa 6 weken leeftijd verhoogde rustplaatsen met roosters geplaatst.

In het algemeen is er weinig onderzoek gedaan naar het gebruik van een verhoogde rustplaats bij vleeskuikenouderdieren. Von Wachenfelt en Berndtson (2014) vergeleken het gebruik van houten Aruiters met zitstokken en met roosters in praktijkstallen voor vleeskuikenouderdieren. Tijdens de opfokperiode werden gedurende de dag $10 \%$ en gedurende de nacht $24 \%$ van de dieren op de verhoogde rustplaatsen aangetroffen. De auteurs vermoeden dat standaard verhoogde roosters mogelijk genoeg zijn om de dieren een schuilplaats te bieden voor de nacht. Verder bleek uit dat onderzoek dat zitstokken meer borstblaren veroorzaakten, maar mogelijk heeft het materiaal en de vorm van de stokken daarin ook een rol gespeeld.

Gebhardt-Henrich et al. (2017) onderzochten het nachtelijk gebruik van verhoogde rustplaatsen (verhoogde roosters en zitstokken boven de voergoot) in de opfok- en de productieperiode bij Ross 308 (reguliere) en Hubbard JA (traag groeiende) vleeskuikenouderdieren. De Hubbard JA dieren maakten meer gebruik van de verhoogde rustplaatsen ( $91 \%$ van de dieren op 20 weken) t.o.v. van de Ross 308 dieren (80\% op 20 weken). Op latere leeftijd bleven de Hubbard JA dieren de verhoogde rustplaatsen veel gebruiken, terwijl de Ross 308 dieren er minder gebruik van maakten (tot ongeveer $50 \%$ ) op 53 weken leeftijd.

In een ander onderzoek, bestudeerden Gebhardt-Henrich et al. (2018) het gebruik van zitstokken tijdens de opfok- en productieperiode bij Ross 308 (reguliere) en Sasso (traag groeiende) vleeskuikenouderdieren. Er werden twee soorten verhoogde rustplaatsen boven de roosters onderzocht: A-ruiters met elk 8 houten zitstokken en volières boven de roosters met houten zitstokken (14 cm zitstok per dier). De zitstokken in de A-ruiters bevonden zich op 25, 50,75, $100 \mathrm{~cm}$ boven de roosters en de volières omvatten vier niveaus met houten zitstokken op 55, 68, 115 en 138 $\mathrm{cm}$ boven de roosters. De dieren gaven in beide opstellingen de voorkeur aan de verhoogde zitstokken boven de andere rustplaatsen (voergoot, roosters en drinklijn) terwijl in de volières relatief meer dieren op de zitstokken verbleven. Borstbeenbreuken werden vaker gezien bij dieren met toegang tot zitstokken (26-32\%). De incidentie van borstbeenbreuken was hoger bij de Sasso dieren (39\%) dan bij de Ross dieren (15\%). De auteurs concludeerden dat vleeskuikenouderdieren de voorkeur geven aan zitstokken om te overnachten ten opzichte van roosters en drinklijnen wat kwam doordat de zitstokken hoger waren aangebracht.

Recent onderzoek op praktijkbedrijven in Nedersaksen (Duitsland) liet zien dat met name gedurende de nacht, vleeskuikenouderdieren (regulier en trager groeiende) veel gebruik maken van zitstokken, en dat het gebruik toeneemt met toenemende leeftijd (Brandes et al., 2017). Dit onderzoek betrof waarnemingen aan praktijkstallen waarbij de zitstokken zowel op het strooisel als op het rooster aangeboden werden. Ouderdieren van trager groeiende kuikens zaten in de lichtperiode meer op de zitstokken dan ouderdieren van snelgroeiende kuikens, maar de bezetting in de donkerperiode was 
voor beide typen ouderdieren gelijk. In de donkerperiode hadden de hoogste zitstokken de voorkeur boven lagere stokken.

Het grootste bezwaar van bovenstaande onderzoeken is dat de verschillende rustplaatsen op verschillende hoogten waren aangebracht en er dus geen sprake was van een goede preferentietest. In een zuivere preferentietest worden de verschillende rustplaatsen op dezelfde hoogte aangeboden om verstrengeling met hoogte te voorkomen. Daarnaast moeten de individuele rustplaatsen (rooster en zitstokken) plaats bieden aan minimaal $75 \%$ van de dieren. Uit onderzoek bij leghennen van Schrader en Müller (2009) bleek namelijk dat het materiaal van de rustplaatsen niet van belang is, maar dat juist de hoogte van de rustplaats de voorkeur bepaald. Dit onderzoek impliceerde dat het aanbieden van een hogere rustplaats aantrekkelijker is voor kippen (en dus ook vleeskuikenouderdieren) omdat een hogere rustplaats meer veiligheid biedt dan een lagere.

Recent heeft ons onderzoeksteam een preferentietest uitgevoerd in een praktijkstal met Ross 308 opfok vleeskuikenouderdieren (van Emous et al., 2018). De dieren hadden de beschikking over 16 verhoogde rustplaatsen op dezelfde hoogte $(50 \mathrm{~cm})$. De rustplaatsen waren afwisselend uitgevoerd met roosters of zitstokken. Per afdeling (twee in totaal) waren 8 verhoogde rustplaatsen met roosters en 8 verhoogde rustplaatsen met metalen (duims) zitstokken (met daarboven in beide gevallen een drinknippellijn) geplaatst. De verhoogde rustplaatsen waren $240 \mathrm{~cm}$ lang en $60 \mathrm{~cm}$ breed en waren voor de dieren beschikbaar vanaf 6 weken leeftijd. De conclusie in dit onderzoek was dat opfok vleeskuikenouderdieren een lichte voorkeur hebben voor roosters ten opzichte van zitstokken (van Emous et al., 2018). In de donkerperiode bevonden zich gemiddeld 21,4 dieren op de verhoogde rustplaatsen met roosters en 19,2 dieren op de verhoogde rustplaatsen met zitstokken. Kanttekening bij dit onderzoek is dat niet alle dieren op de verschillende rustplaatsen konden rusten gedurende de nacht waardoor er mogelijk een verdringingseffect is ontstaan.

Samenvattend kan worden gesteld dat vleeskuikenouderdieren in de productieperiode tijdens de lichten donkerfase een voorkeur laten zien tot een verhoogde rustplaats in vergelijking met het strooisel.

Op het gebied van verhoogde rustplaatsen of zitstokken is er voor vleeskuikenouderdieren binnen de EU geen regelgeving voorgeschreven. Enkele landen of regio's (bijv. Nederland, Zweden en Nedersaksen) stellen wel eisen aan zitstokken bij vleeskuikenouderdieren (Gebhardt-Henrich et al., 2018). In Nederland is het aanbieden van zitstokken bij vleeskuikenouderdieren vastgelegd in de 'Verordening Welzijnsnormen Vleeskuikenouderdieren' (Productschap Pluimvee en Eieren, 2006; 2010). In deze verordening staat onder Artikel 4 lid c: 'in de stal zijn horizontaal aangebrachte houten of kunststoffen zitstokken of latten beschikbaar die een lengte hebben van tenminste $7 \mathrm{~cm}$ per vleeskuikenouderdier; de zitstokken of latten hebben zowel naar boven als naar beneden een vrije ruimte die naar boven tenminste $35 \mathrm{~cm}$ en naar beneden tenminste $10 \mathrm{~cm}$ bedraagt'.

In de praktijk werden echter geen extra zitstokken aangebracht, de aanwezige roosters waren voldoende als verhoogde rustplaats. Door het ontbinden van het Productschap Pluimvee en Eieren is de handhaving van de Verordening Welzijnsnormen Vleeskuikenouderdieren overgegaan naar de NVWA. Naar aanleiding van controles bij praktijkbedrijven met vleeskuikenouderdieren bleken de regels en de praktijksituatie betreffende het aanbieden van rustplaatsen niet overeen te komen. Met name het ontbreken van zitstokken in praktijkstallen werd opgemerkt door de NVWA. In de opfokperiode wordt gebruik gemaakt van verhoogde rustplaatsen met roosters (springtafels). Tijdens de legperiode hebben de ouderdieren de beschikking over circa 30 tot $65 \%$ roostervloer. Roosters (in principe een verzameling zitstokken) zijn een goed alternatief voor zitstokken, omdat deze verhoogd zijn geïnstalleerd. Tot nu toe is nauwelijks objectief vergelijkend onderzoek gedaan naar het gebruik van een verhoogde rustplaats bij vleeskuikenouderdieren. De voorkeur voor een verhoogd rooster of een zitstok is bij vleeskuikenouderdieren dus onbekend.

Het doel van dit onderzoek was om te bepalen of vleeskuikenouderdieren, tijdens de productieperiode, een voorkeur vertonen voor een roostervloer of zitstokken als verhoogde rustplaats gedurende de nacht. Om uit te sluiten dat de voorkeur voor de hoogste rustplaats mee speelt, zijn deze rustplaatsen op dezelfde hoogte aangebracht. 


\section{$2 \quad$ Materiaal en methoden}

\section{$2.1 \quad$ Dieren en verzorging}

De studie werd uitgevoerd met vleeskuikenouderdieren tussen 40 en 60 weken leeftijd. Deze dieren waren afkomstig uit een voorgaand experiment tussen 0 en 40 weken leeftijd waarbij de dieren tijdens de opfokperiode verschillende voerstrategieën kregen. Voor aanvang van het huidige experiment (40 weken leeftijd) werden de dieren geselecteerd en gerandomiseerd. Daarbij werden te lichte, te zware, niet-leggende en verwonde dieren verwijderd. De resterende hennen werden random over de verschillende hokken verdeeld om een neutrale aanvangssituatie te creëren die onafhankelijk was van de voorafgaande behandeling van de dieren. De hanen uit het voorgaande experiment werden ook gerandomiseerd. Het experiment werd gestart met 26 hennen en 3 hanen per hok (Ross 308). Tijdens het experiment werden de dieren dagelijks tweemaal door de dierverzorger gecontroleerd op welzijn en afwijkingen en eventuele uitval werd verwijderd en genoteerd. Dieren met een geconstateerde afwijking werden na overleg met de onderzoekers uit de proef verwijderd. Dagelijks werd de omgevingstemperatuur en relatieve luchtvochtigheid gemeten (ochtend en middag).

\subsection{Accommodatie}

Voorperiode ( $0 \mathrm{t} / \mathrm{m} 40$ weken leeftijd)

Voor de experimentele periode ( $40 \mathrm{t} / \mathrm{m} 60$ weken leeftijd) hadden de dieren vanaf 6 weken leeftijd al de beschikking over zowel een rooster als zitstokken, hierdoor waren de dieren al gewend aan beide mogelijkheden. Vanaf 6 weken leeftijd werd een kunststof rooster geplaatst $(150 \times 60 \mathrm{~cm}$ op $50 \mathrm{~cm}$ hoogte). De dieren hadden vanaf die leeftijd tevens de beschikking over 2 kunststof zitstokken van elk $2 \mathrm{~m}$ lang (op 55 en $65 \mathrm{~cm}$ hoogte). Dit is in Bijlage 1 (linker figuur) schematisch weergegeven.

Experimentele periode ( $40 \mathrm{t} / \mathrm{m} 60$ weken leeftijd)

De vleeskuikenouderdieren waren gehuisvest in afdeling 1 en 2 van proeffaciliteit Carus in Wageningen. Op 40 weken leeftijd werd het kunststof rooster vervangen door een (groter) houten rooster $(150 \times 100 \mathrm{~cm}$ ) op $50 \mathrm{~cm}$ hoogte (Bijlage 1 rechter figuur). De beide kunststof zitstokken van elk $2 \mathrm{~m}$ lang ( $4 \mathrm{~m}$ totaal per hok) waren beiden op $50 \mathrm{~cm}$ hoogte geplaatst. De zitstokken waren rechthoekig met afgeronde hoeken (breedte: $4 \mathrm{~cm}$ en hoogte: $3 \mathrm{~cm}$ ).

Beide afdelingen waren mechanisch geventileerd en bevatten 2 rijen met 6 hokken (12 hokken per afdeling en in totaal 24 hokken). De hokken waren 2,5 m diep en 2,0 m breed. De dieren werden gehouden bij een bezetting van ca. $1.700 \mathrm{~cm}^{2} /$ dier (hennen en hanen).

Voor aanvang van het experiment werd het oude strooisel verwijderd en een laagje nieuwe houtkrullen over de vloer verspreid $\left(2 \mathrm{~kg} / \mathrm{m}^{2}\right)$. Bij een slechte strooiselkwaliteit werd in alle hokken eenzelfde hoeveelheid bijgestrooid.

De voervoorziening voor de hennen bevond zich op het strooisel in 2 voergoten (totaal 3,7 m lengte) per hok, met een grill om toegang van de hanen uit te sluiten. Hanen werden gevoerd via een aparte voergoot op $50 \mathrm{~cm}$ hoogte die niet bereikbaar was voor de hennen. Water werd tussen 07:30 en 16:30 verstrekt via een drinknippellijn (7 nippels/hok op het rooster). In de namiddag (15:00 uur) kregen de dieren 2 gram/dier strooigraan op het strooisel verstrekt.

De lichtperiode stond ingesteld op 14 uur licht (02:30 t/m 16:00 uur) en de lichtsterkte was minimaal 40 lux op kophoogte. Schaduwplekken werden zoveel mogelijk geminimaliseerd om grondeieren te voorkomen. Gedurende het experiment stond de streeftemperatuur ingesteld op $20^{\circ} \mathrm{C}$. Gedurende de dag was er een radio met geluid om de dieren rustiger te houden.

\subsection{Proefopzet}

De studie was opgezet als een preferentietest waarbij alle 24 hokken precies hetzelfde waren ingericht met verschillende rustplaatsen. Daarbij hadden de dieren de beschikking over 2 verschillende rustplaatsen: hardhouten rooster $(150 \times 100 \mathrm{~cm})$ en 2 kunststof zitstokken (rechthoekig met 
afgeronde hoeken: totaal $4 \mathrm{~m}$ lengte) (Figuur 1). De zitstokken waren op dezelfde hoogte geplaatst als het rooster $(50 \mathrm{~cm})$. Het water bevond zich voor het legnest op het rooster.

Doordat de twee verhoogde rustplaatsen (rooster en zitstokken) uit verschillend materiaal en vorm bestonden, is berekend of beide rustplaatsen ( $\mathrm{min}$ of meer) dezelfde capaciteit hadden. Om dit te berekenen is uitgegaan van informatie uit de literatuur over de benodigde oppervlakte (rustplaats met roosters) en breedte (rustplaats met zitstokken) voor een zittend dier. Voor de benodigde oppervlakte $\left(\mathrm{cm}^{2}\right)$ voor een zittend dier is gebruik gemaakt van de volgende formule van Baxter $(1992):=0,035 *$ $\mathrm{W}^{0,67} * 10.000\left(\mathrm{~W}=\right.$ diergewicht in $\mathrm{kg}$ ). Een dier van $4 \mathrm{~kg}$ heeft een oppervlakte van $886 \mathrm{~cm}^{2}$ nodig. De rustplaatsen met roosters waren $150 \mathrm{~cm}$ breed en $100 \mathrm{~cm}$ diep (oppervlakte: $15.000 \mathrm{~cm}^{2}$ ). Doordat de dieren echter vaak aan de zijkanten van de roosters zaten was het werkelijk beschikbare oppervlakte groter. Ingeschat wordt dat aan alle kanten de dieren ca. $10 \mathrm{~cm}$ extra ruimte konden gebruiken wat het beschikbaar oppervlakte $20.400 \mathrm{~cm}^{2}(170 \times 120 \mathrm{~cm})$ maakt. Tijdens de tellingen viel het op dat er regelmatig meer dieren op het rooster zaten dan er volgens berekeningen maximaal op konden rusten.

Voor een zittend dier op een zitstok is gerekend met $20 \mathrm{~cm}$ breedte bij een dier van $4 \mathrm{~kg}$. Dit is bepaald door op verschillende leeftijden de breedte van de dieren te bepalen. Uit de berekeningen blijkt dat op de roosters en zitstokken plaats was voor respectievelijk 23 en 20 dieren.

Naast de twee verhoogde rustplaatsen hadden de dieren ook de mogelijkheid om te rusten op het strooisel, en door praktische omstandigheden ook op de drinklijn en in het legnest (niet afsluitbaar). Op de drinklijn en in het legnest was ongeveer plaats voor 5-6 dieren.

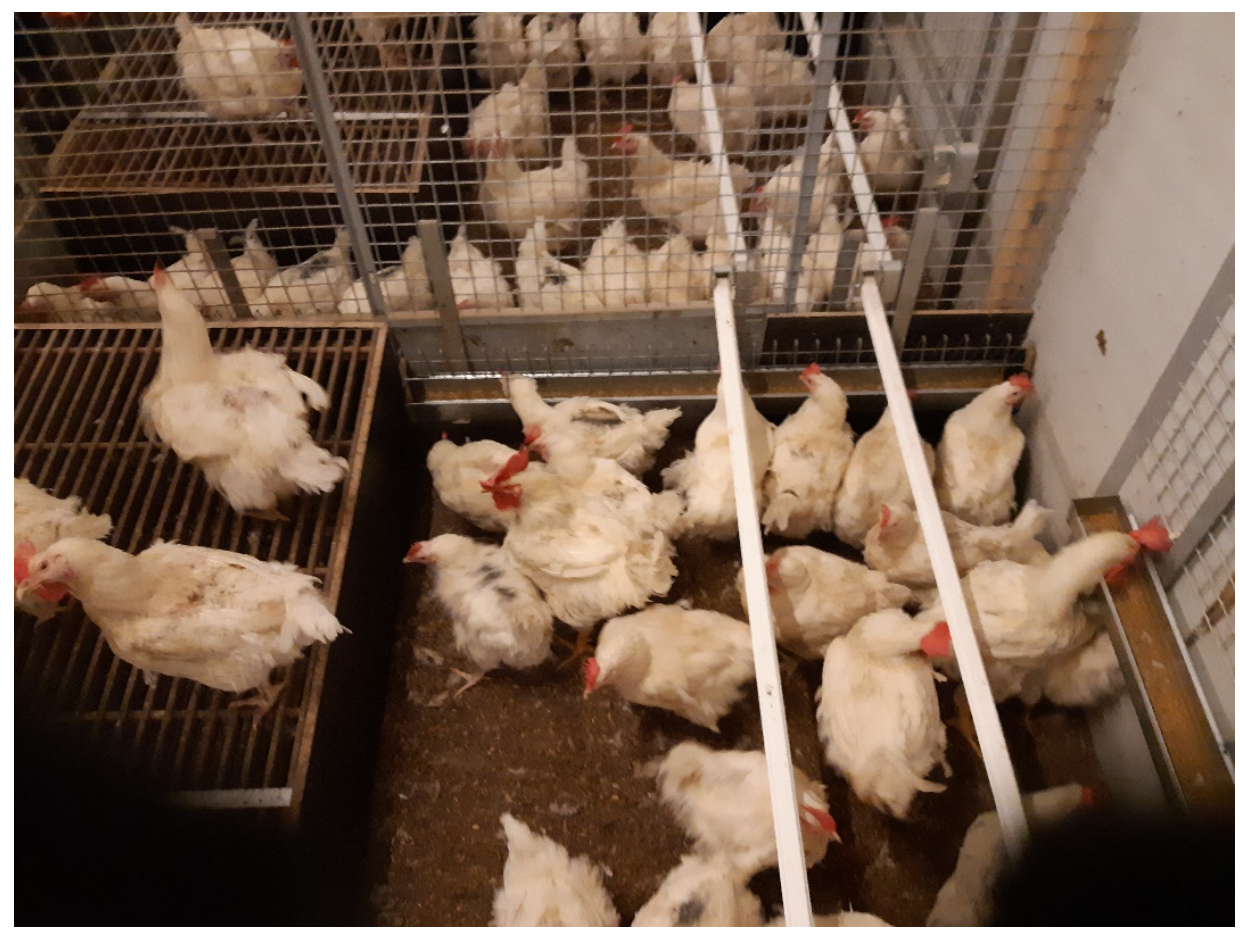

Figuur 1 Bovenaanzicht van een van de experimentele hokken. Links het houten rooster met daarboven de drinklijn (niet zichtbaar). Rechts de 2 kunststof zitstokken met daaronder het strooisel. Links naast het houten rooster bevond zich het legnest (niet zichtbaar).

\subsection{Waarnemingen}

De volgende waarnemingen zijn uitgevoerd:

- Iedere week (dinsdag of woensdag) werden, ongeveer een half uur nadat het licht was uitgegaan, tellingen uitgevoerd naar het aantal dieren dat zich op de verschillende rustplaatsen bevond: rooster, zitstokken, drinklijn, strooisel of legnest.

- Binnen een hok werden 3 hennen individueel herkenbaar gemaakt (focal animals) middels een kleurcode op de vleugels (d.m.v. een merkstift voor varkens). Dit werd gedaan door of enkel de linkervleugel, enkel de rechtervleugel of beide vleugels blauw te kleuren. De kleuring werd ongeveer iedere 2 weken opnieuw aangebracht. De rustplaats van de 3 gemerkte dieren werd geobserveerd 
om inzicht te krijgen in de persistentie van de voorkeur voor de rustplaats en om de gevolgen van de rustplaats op de bevedering en borstblaren te volgen.

- Op 46, 50, 55 en 60 weken leeftijd werd van de gemerkte dieren de bevedering en de aanwezigheid van borstblaren beoordeeld. Bevedering werd gescoord op 7 onderdelen per dier (nek, borst, buik, rug, vleugels, staart en flanken). Borstblaren werden gescoord van 0 (geen borstblaar) tot 5 (borstblaar met grootte van een ei).

- Op 55 en 59 weken leeftijd werd tijdens de donkerperiode van 5 random dieren op de rustplaatsen rooster, zitstokken en drinklijn, de aanwezigheid van borstblaren beoordeeld. Borstblaren werden gescoord van 0 (geen borstblaar) tot 5 (borstblaar met grootte van een ei).

\subsection{Berekeningen en statistische analyse}

De data werd geanalyseerd m.b.v. Genstat (2018) software. De $P$-waarde van het behandelingseffect en de SEM zijn per responsparameter weergegeven (indien van toepassing). Behandelingseffecten met een $P$-waarde $\leq 0,05$ werden als statistisch significant beschouwd.

De rustplaats preferentie is vastgesteld door de wekelijks tellingen van het aantal dieren op de verschillende rustplaatsen, omgerekend naar het percentage dieren. Het gemiddelde is bepaald op hokniveau van het totaal aantal waarnemingen (20 weken), omdat deze opeenvolgende waarnemingen niet onafhankelijk van elkaar zijn. De gemiddelde data per hok werd geanalyseerd via een ANOVA (variantieanalyse) met als hoofdeffect rustplaats (rooster, zitstokken, drinklijn, legnest en strooisel, en als random effect het hok.

Voor de bepaling van de consistentie van de 72 individueel gemerkte dieren zijn de tellingen gebruikt van de wekelijkse waarnemingen van de rustplaats per individueel dier. Met die gegevens kon het aantal weken waarop een individueel dier op dezelfde rustplaats in de tijd verbleef worden bepaald. Hieruit volgde per dier het aantal gebruikte rustplaatsen in de tijd en het aantal verblijven (consistentie) op dezelfde rustplaats (rooster, zitstokken, drinklijn, legnest en strooisel). Beide aantallen zijn omgerekend naar percentages. Daarnaast is het gemiddelde van de consistentie van alle dieren over de verschillende rustplaatsen berekend.

De bevedering is geanalyseerd met linear mixed models (REML) met rustplaats als hoofdeffect en hok als random effect.

Prevalentie van borstblaren van individuele dieren is alleen meegenomen in de analyse als de dieren in de voorgaande weken $70 \%$ op dezelfde rustplaats verbleven. Op 46, 50, 55 en 60 weken leeftijd werden alleen de dieren die respectievelijk 4, 7, 10 en 14 maal op dezelfde rustplaats zijn waargenomen, meegenomen in de analyses. Het gemiddelde van de prevalentie en de borstblaarscore werden bepaald per observatiedag en per rustplek. Vervolgens werden de parameters per observatiedag met een ANOVA geanalyseerd met rustplaats als hoofdeffect en hok als random effect. 


\section{$3 \quad$ Resultaten en discussie}

\subsection{Verloop proef}

Het experiment tussen 40 en 60 weken leeftijd is goed verlopen, de dieren waren gezond en ze produceerden in deze periode 107 eieren terwijl 87 eieren de norm is. Dit werd mede veroorzaakt doordat de dieren 2,5 week te laat in productie kwamen doordat de afdelingen tijdens de opfokperiode niet volledig donker waren. Verder was de uitval, tijdens het experiment, met 1,3\%, t.o.v. de norm van $4,0 \%$ erg laag. De hoge productie en lage uitval werd ook veroorzaakt doordat de aantallen dieren per hok op 40 en 50 weken leeftijd zijn teruggebracht naar respectievelijk 26 en 24 stuks. Hierdoor werden de slechtere, en mogelijk ook niet (goed) productieve dieren uitgeselecteerd.

\subsection{Gebruik verschillende rustplaatsen}

Doel van het onderzoek was het bestuderen van de voorkeur voor rustplaats gedurende de donkerperiode van vleeskuikenouderdieren. Gemiddeld genomen over de gehele experimentele periode van 20 weken, rustten $51,5 \%$ van de dieren 's nachts op het rooster (Tabel 1 ). Op de zitstokken rustten gemiddeld $23,9 \%$, op de drinklijn $11,2 \%$, in het legnest $9,2 \%$ en op het strooisel $4,2 \%$.

Tabel 1 Gemiddeld percentage dieren op (rooster, zitstokken, drinklijn en strooisel) of in (legnest) de verschillende rustplaatsen gedurende de gehele experimentele periode van 20 weken (40-60 weken leeftijd).

\begin{tabular}{ll} 
Rustplaats & Dieren $(\%)$ \\
Rooster & $51,5^{\mathrm{a}}$ \\
\hline Zitstokken & $23,9^{\mathrm{b}}$ \\
\hline Drinklijn & $11,2^{\mathrm{c}}$ \\
\hline Legnest & $9,2^{\text {cd }}$ \\
Strooisel & $4,2^{\mathrm{e}}$ \\
\hline a-e Verschillende letters geven een verschil aan $(P<0,05)$. &
\end{tabular}

Het percentage dieren per rustplaats op weekniveau bleef gedurende de gehele experimentele periode heel constant (Figuur 2). Het percentage dieren op het rooster schommelde licht tussen 50 en $53 \%$. Het percentage dieren op de zitstokken nam licht af tussen 43 en 60 weken leeftijd van maximaal $27 \%$ op 43 weken leeftijd naar $20 \%$ op 60 weken leeftijd. Mogelijk dat dit kwam door het toenemende gewicht van de dieren en de verminderde mobiliteit bij het ouder worden. Het aandeel dieren op de drinklijn schommelde tussen 10 en 12,5\%. In het algemeen viel op dat in de meeste hokken de drinklijn steeds bijna maximaal bezet was. Dit heeft mogelijk te maken met het feit dat de drinklijn hoger was geplaatst dan het rooster en de zitstokken. Uit het onderzoek van Schrader en Müller (2009) met leghennen bleek dat de hoogte van een rustplaats belangrijker is dan het materiaal of vorm. Het gebruik van het legnest als rustplaats nam toe in de tijd van 7,5 naar $11,5 \%$. Dit is normaal gedrag omdat bij het ouder worden er relatief meer dieren zijn die worden aangepikt waardoor deze dieren een veilige omgeving vinden in het legnest. Mogelijk dat ook een aantal dieren die in de rui gingen (verblijven op het legnest) dit percentage beïnvloed hebben. Het aandeel dieren op het strooisel nam eerst af van 7,5 naar 3,5\% om bij het ouder worden van de dieren weer toe te nemen (6\%). De afname in het begin van de experimentele periode kwam mogelijk doordat de dieren meer roosteroppervlakte kregen (van $150 \times 60 \mathrm{~cm}$ naar $150 \times 100 \mathrm{~cm}$ ). Dat het later weer wat afnam heeft mogelijk te maken met het hogere gewicht en verminderde mobiliteit van de dieren. Opvallend bij het strooisel was dat voornamelijk de hanen hiervan gebruik maakten wat overeen komt met waarnemingen in de praktijk (Joan van Haandel, persoonlijke mededeling).

In het experiment konden de legnesten, in tegenstelling tot de praktijk, niet worden afgesloten wat mogelijk de resultaten heeft beinvloed. In de praktijk wordt een uur voordat het licht uitgaat de dieren in de legnesten via een uitdrijfsysteem uit het nest verwijderd en blijven dan op het rooster. Het is daarom aannemenlijk dat bij een afsluitbaar legnest het aandeel dieren op het rooster circa $60 \%$ was geweest. 


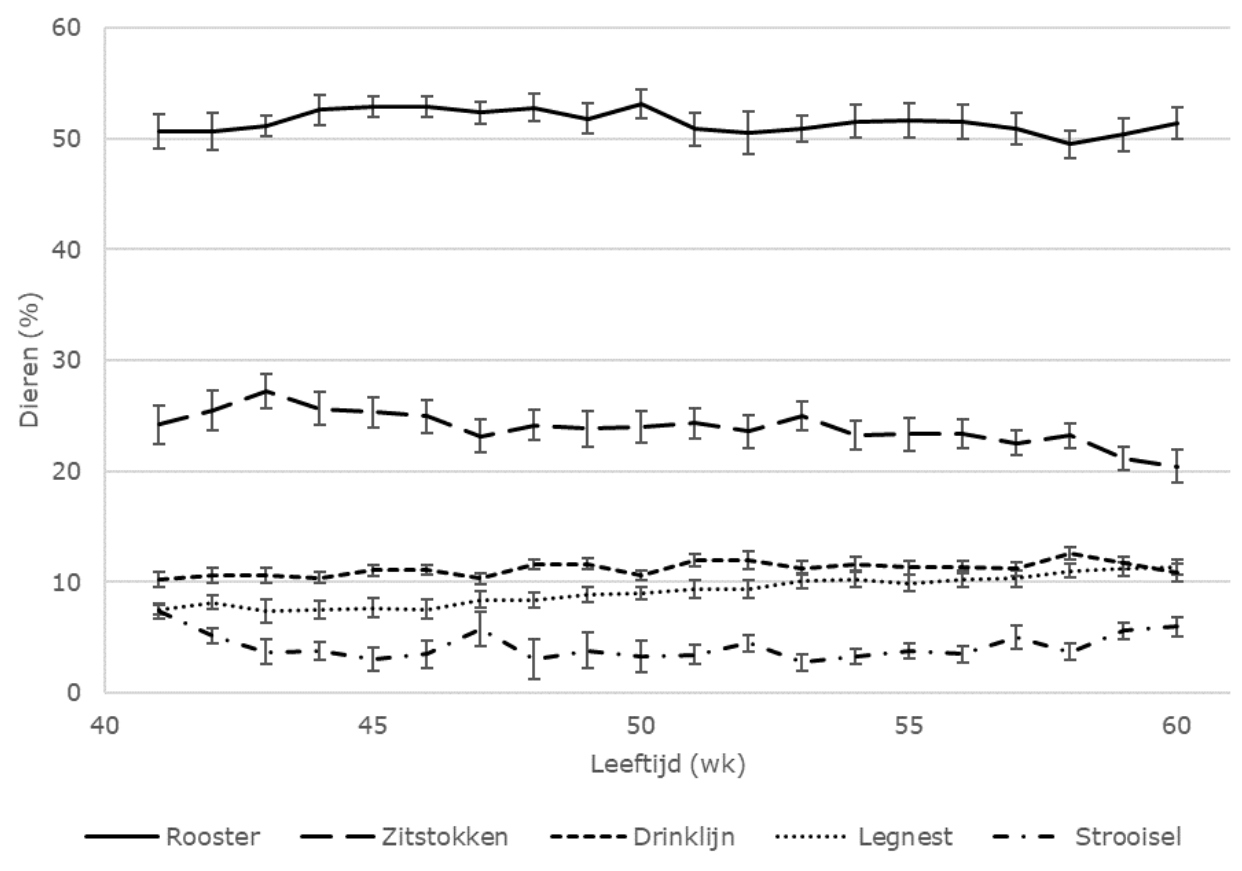

Figuur 2 Percentage dieren (+SEM) op of in de verschillende rustplaatsen in de tijd.

De voorkeur voor het rooster boven de zitstokken komt overeen met de uitkomsten van de recent uitgevoerde preferentietest met opfok vleeskuikenouderdieren (van Emous et al., 2018). Op de verhoogde rustplaatsen met roosters werden gemiddeld 21,4 dieren waargenomen en op de verhoogde rustplaatsen met zitstokken 19,2 dieren. Vergelijkingen met het onderzoek van Von Wachenfelt en Berndtson (2014), Gebhardt-Henrich et al. (2017; 2018) en Brandes et al. (2017) zijn niet mogelijk omdat in al die experimenten de verschillende rustplaatsen op verschillende hoogten waren aangebracht en er geen sprake was van een zuivere preferentietest. Zoals eerder genoemd moet verstrengeling met hoogte worden voorkomen, omdat uit onderzoek van Schrader en Müller (2009) bleek dat de hoogte meer van belang is dan het materiaal van het rustplaats.

Over dit onderwerp zijn verder geen vergelijkbare preferentietesten met ouderdieren beschikbaar. Studies met vleeskuikens laten echter een vergelijkbare preferentie zien voor nachtelijk rustten op roosters boven zitstokken (Oester et al., 2005; de Jong en van Wijhe-Kiezebrink, 2014; Norring et al., 2016; Malchow et al., 2019).

Gebruik rustplaatsen in de voorperiode

Zoals opgemerkt hadden de dieren in de voorperiode (20 tot 40 weken leeftijd) van dit experiment de beschikking over een (kunststof) rooster en 2 kunststof zitstokken. Tijdens deze periode zijn tweewekelijks tellingen in de donkerperiode uitgevoerd als pilot. In bijlage 2 is de grafiek weergegeven van de resultaten van die voorperiode en experimentele periode. Uit de grafiek in de bijlage blijkt dat er tijdens de overgang van de voorperiode naar de experimentele periode er geen grote verschuivingen optraden in het gebruik van de verschillende rustplaatsen. Het percentage dieren dat gebruik maakten van het rooster, zitstokken en drinklijn verschilde nauwelijks tussen de voor- en experimentele periode. Het percentage dieren in het legnest nam echter toe van gemiddeld 5,3 naar $9,2 \%$ terwijl er een omgekeerd effect was voor het percentage dieren op het strooisel (van 9,7 naar $4,2 \%$ ). Dit komt mogelijk door het plaatsen van de legnesten op 20 weken leeftijd, waarbij de interesse voor de nesten gedurende de tijd groeide.

\subsection{Gebruik rustplaats in de tijd van individuele dieren}

Per hok waren drie dieren (72 in totaal) individueel gemerkt. Hierdoor kon geobserveerd worden of individuele dieren voor dezelfde rustplaats kozen of juist wisselden. Daarnaast konden eventuele veranderingen in het gebruik van de rustplaatsen in de tijd in kaart worden gebracht. Uit de waarnemingen blijkt dat $28 \%$ van de dieren gedurende de gehele experimentele periode van twintig 
weken op of in dezelfde rustplaats werd waargenomen (Figuur 3). Verder gebruikte $46 \%$ van de dieren twee verschillende rustplaatsen, $22 \%$ van de dieren drie verschillende rustplaatsen en slechts $4 \%$ wisselde tussen vier verschillende rustplaatsen.

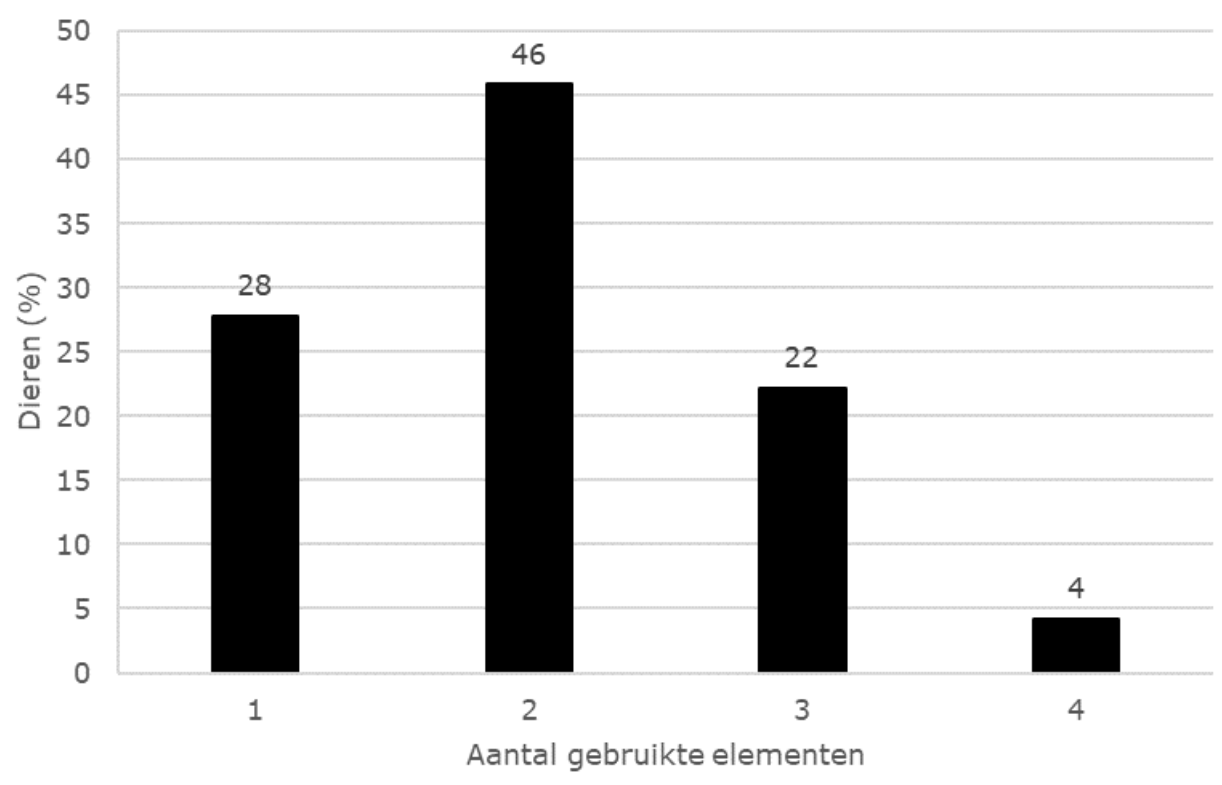

Figuur 3 Percentage gemerkte dieren dat gebruik maakte van verschillende rustplaatsen.

Het percentage dieren dat steeds dezelfde rustplaats gebruikte gedurende de nacht verschoof in de tijd (Figuur 4). Op 41 weken leeftijd ( $1^{\mathrm{e}}$ waarneming) maakte $100 \%$ van de dieren gebruik van dezelfde rustplaats, wat gemiddeld over alle rustplaatsen daalde naar $28 \%$ op 60 weken leeftijd. De dieren waren dus redelijk consistent in de keuze van hun rustplaats in de tijd. De consistentie van het gebruik van het rooster, zitstokken en legnest nam af van 100\% naar respectievelijk 48, 25 en $8 \%$ tussen 41 en 60 weken oud. De consistentie van de keuze voor de drinklijnen en strooiselgebruik was minder, en was al $0 \%$ op respectievelijk 51 en 45 weken leeftijd. Geconcludeerd kan worden dat het rooster voor de dieren aantrekkelijk was om gedurende een langere periode 's nachts op te rusten in vergelijking met de andere rustplaatsen.

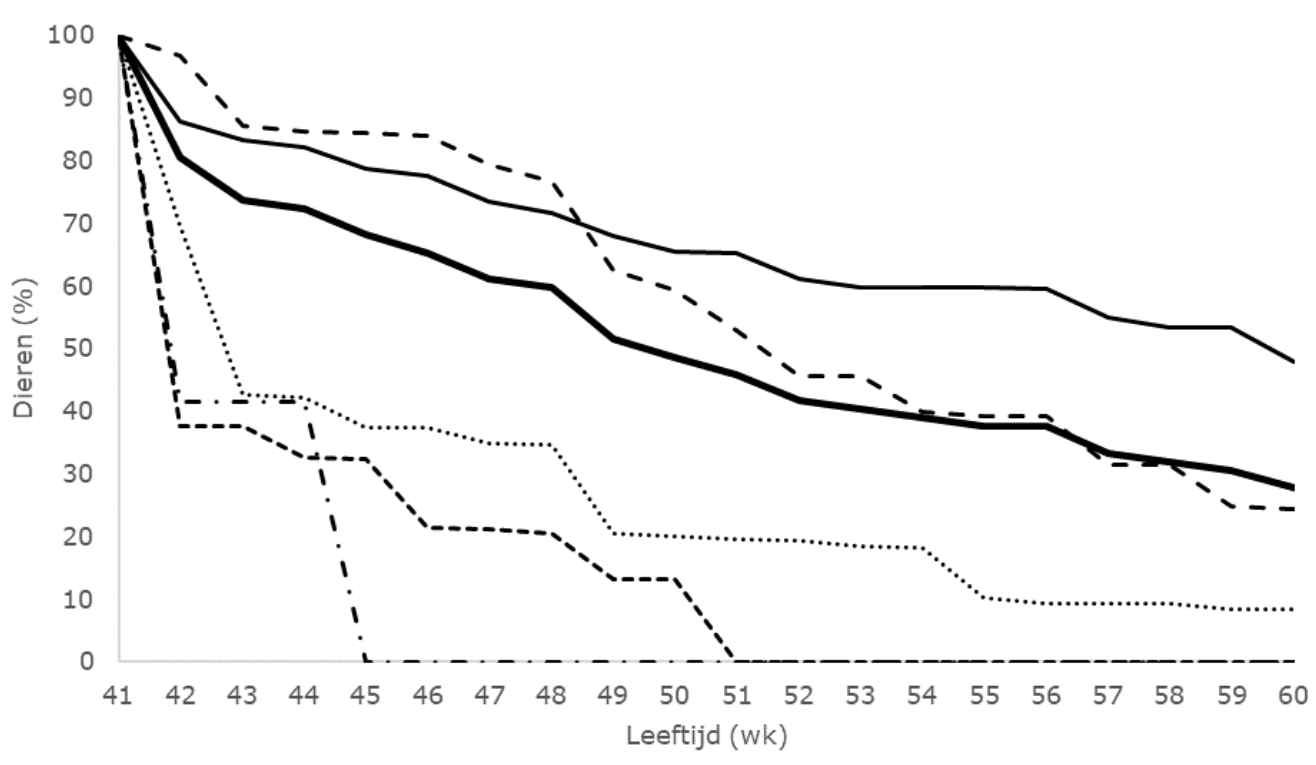

— Rooster - - - Zitstokken - - --Drinklijn ......... Legnest - . - Strooisel _ Gemiddeld

Figuur 4 Verloop van het percentage gemerkte dieren in de tijd dat gebruik maakten van de verschillende rustplaatsen en het gemiddelde. 
Het specifieker bekijken van de consistentie laat zien dat de dieren behoorlijk honkvast waren. Tabel 2 geeft het aantal weken uit de experimentele periode van 20 weken weer dat een individueel dier gebruik heeft gemaakt van dezelfde rustplaats. De tabel geeft enkel het overzicht van 10 weken of meer op dezelfde rustplaats. Dit is omdat een dier dat bijvoorbeeld 15 keer op dezelfde rustplaats is geobserveerd, ook 5 weken op één (of meerdere) rustplaatsen is geobserveerd, en voor die resterende 5 keer niet meer uniek geteld kon worden. Onafhankelijk van de soort rustplaats, bleek wederom dat bijna $28 \%$ van de dieren 20 weken op dezelfde rustplaats heeft gezeten, iets meer dan $18 \%$ zat 19 weken op dezelfde rustplaats en bijna $17 \%$ zat 17 van de 20 weken op dezelfde rustplaats. Cumulatief betekent dit dat bijna $80 \%$ van de dieren 15 keer of vaker in de gehele periode op dezelfde rustplaats werd waargenomen. Deze resultaten suggereren dat de dieren gehecht raakten aan een bepaalde rustplaats en vaak terugkeerden naar dezelfde plaats om 's nachts te rustten. Vanuit onderzoek met leghennen (Cordiner en Savory, 2001) is bekend dat gedurende de nacht vooral de rang-hoge dieren mogelijk het meest consistent waren en andere wegjaagden van hun rustplaats. Verder speelt mogelijk ook mee, dat wanneer de rustplaats al flink bezet was, enkele dieren de voorkeur gaven voor hun $2^{\mathrm{e}}$ geprefereerde rustplaats. Tevens kan het zijn dat dieren met (ernstige) borstblaren van rustplaats veranderde (bv. van zitstok naar rooster).

Tabel 2 Overzicht van het aantal weken (van 20 weken experimentele periode) dat dieren gebruik maakten van dezelfde rustplaats (percentage).

\begin{tabular}{lll}
$\begin{array}{l}\text { Aantal weken op hetzelfie } \\
\text { rustplaats }\end{array}$ & Dieren $(\%)$ & Cumulatief $\%$ \\
20 & 27,8 & 27,8 \\
\hline 19 & 18,1 & 45,8 \\
\hline 18 & 9,7 & 55,6 \\
\hline 17 & 15,3 & 70,8 \\
\hline 16 & 5,6 & 76,4 \\
\hline 15 & 2,8 & 79,2 \\
\hline 13 & 0,0 & 79,2 \\
\hline 12 & 4,2 & 83,3 \\
\hline 11 & 2,8 & 86,1 \\
\hline
\end{tabular}

Alhoewel de meeste gemerkte dieren consistent op het rooster (53\%) of op een zitstok (29\%) verbleven gedurende de nacht, zijn ook enkele dieren minimaal 10 maal van de 20 weken consistent geobserveerd op de drinklijn (4\%), in het legnest (10\%) of op het strooisel (4\%).

\subsection{Bevedering}

In Tabel 3 zijn de resultaten van de bevederingsscore van de gemerkte dieren weergegeven. Er werden geen verschillen aangetroffen in bevedering tussen de dieren die op het rooster, zitstokken of drinklijn verbleven. De voorkeur voor een bepaalde rustplaats lijkt dus geen invloed te hebben op de bevedering van de dieren.

Tabel 3 Gemiddelde bevederingscore in de tijd van de gemerkte dieren gerelateerd aan de rustplaats waarop de dieren zich het meeste bevonden gedurende de nacht*.

\begin{tabular}{llllll}
$\begin{array}{l}\text { Leeftijd } \\
\text { (weken) }\end{array}$ & Rooster & Zitstokken & Drinkijn & SEM & P-waarde \\
46 & 2,6 & 2,4 & 2,3 & 0,4 & 0,400 \\
\hline 50 & 2,5 & 2,2 & 2,3 & 0,3 & 0,115 \\
\hline 55 & 2,8 & 2,7 & 2,6 & 0,3 & 0,337 \\
\hline 60 & 2,9 & 2,6 & 2,6 & 0,3 & 0,121 \\
\hline
\end{tabular}

*Scores tussen 0 (gaaf) en 5 (kaal). 


\subsection{Prevalentie borstblaren}

In Tabel 4 is de prevalentie van borstblaren in de tijd weergegeven van de gemerkte dieren op de verschillende rustplaatsen. Bij deze beoordeling zijn alleen de dieren meegenomen die consistent (minimaal 75\% van de waarnemingen) op het rooster, drinklijn of zitstok rustten. Dieren met een voorkeur voor zitstokken hadden een hogere prevalentie (gemiddeld 45,0\% t.o.v. 11,3\%) aan borstblaren t.o.v. de dieren met een voorkeur voor het rooster. De meeste borstblaren werden echter aangetroffen bij de dieren met een voorkeur voor de drinklijn (gemiddeld $81,7 \%$ ). Verder valt op dat in het algemeen de incidentie borstblaren bij de verschillende rustplaatsen toenam in de tijd. Dit is logisch omdat borstblaren ontstaan door langdurige druk op de slijmbeurs van het borstbeen die vervolgens vergroot en gevuld wordt met vloeistof (McCune en Dellmann, 1968). Zij beschrijven borstblaren als volgt: "ontwikkeling van sponsachtig weefsel onder de huid dat vooraf gaat aan de vorming van een grote blaar die een eiwitachtige vloeistof bevat". Op oudere leeftijd hebben de ouderdieren vaker op een oppervlakte overnacht waardoor de mechanische 'druk/belasting' op hetzelfde kleine oppervlak (met name zitstokken en drinklijn) toeneemt met een grotere kans op het ontwikkelen van een borstblaar. Dit geeft dus gedurende een langere periode steeds druk op dezelfde plek, waardoor een borstblaar kan ontstaan. Bij een rooster is de puntbelasting minder omdat de druk over een groter oppervlakte verdeeld wordt. Desalniettemin komen er ook op het rooster toch bij meer dan $10 \%$ van de dieren borstblaren voor.

Tabel 4 Gemiddelde prevalentie van borstblaren (\% dieren) in de tijd van de gemerkte dieren gerelateerd aan de rustplaats en de leeftijd waarop de dieren zich het meeste bevonden gedurende de nacht.

\begin{tabular}{llllll} 
& Rooster & Zitstokken & Drinkijn & SEM & P-waarde \\
46 & 0,0 & 26,8 & 66,7 & 22,0 & 0,215 \\
\hline 50 & $15,6^{c}$ & $46,7^{b}$ & $83,3^{a}$ & 10,4 & 0,025 \\
\hline 55 & $16,9^{c}$ & $50,5^{b}$ & $100,0^{a}$ & 6,7 & 0,012 \\
\hline 60 & $12,6^{c}$ & $56,1^{b}$ & $83,3^{a}$ & 8,9 & 0,035 \\
\hline Gemiddeld & $11,3^{c}$ & $45,0^{b}$ & $81,7^{a}$ & 11,6 & 0,035
\end{tabular}

a-c Verschillende letters in dezelfde rij geven een verschil aan $(P<0,05)$.

Naast de hogere prevalentie aan borstblaren bij de dieren op de zitstokken en drinklijn t.o.v. de dieren op het rooster hadden de dieren op de zitstokken en drinklijn ook grotere en ernstigere borstblaren (Figuur 5). Dieren die rustten op de drinklijn hadden voornamelijk borstblaren met een score van 1 (32\%), 2 (30\%) of $3(20 \%)$ terwijl slechts $18 \%$ een 1 scoorde. Bij de dieren met voorkeur voor de zitstok werd het meeste score $1(18 \%)$ en $2(17 \%)$ geobserveerd, maar ook zijn ernstige gevallen gevonden met een score van $3(6 \%), 4(3 \%)$ en zelfs $5(2 \%)$. Bij het rooster werd slechts bij respectievelijk 7 en $3 \%$ van de dieren een 1 of 2 gescoord. De gemiddelde score voor het rooster, de zitstokken en de drinklijn was respectievelijk $0,2,0,9$ en 1,5 $(P=0,012)$. De verschillen tussen de rustplaatsen werd waarschijnlijk veroorzaakt door de verschillende mate van belasting door de verschillende rustplaatsen. Dieren die op de zitstokken en drinklijn zaten zullen een grotere puntbelasting op een klein oppervlak van het borstbeen ervaren hebben dan de dieren die op het rooster zaten. Dit zal een verhoogde kans geven op het optreden van een borstblaar en ook een verhoogde kans op het ontwikkelen van een grotere borstblaar. Bij een rooster wordt het gewicht van het dier verdeeld over een groter oppervlakte met kleinere kans op puntbelasting op het borstbeen. 


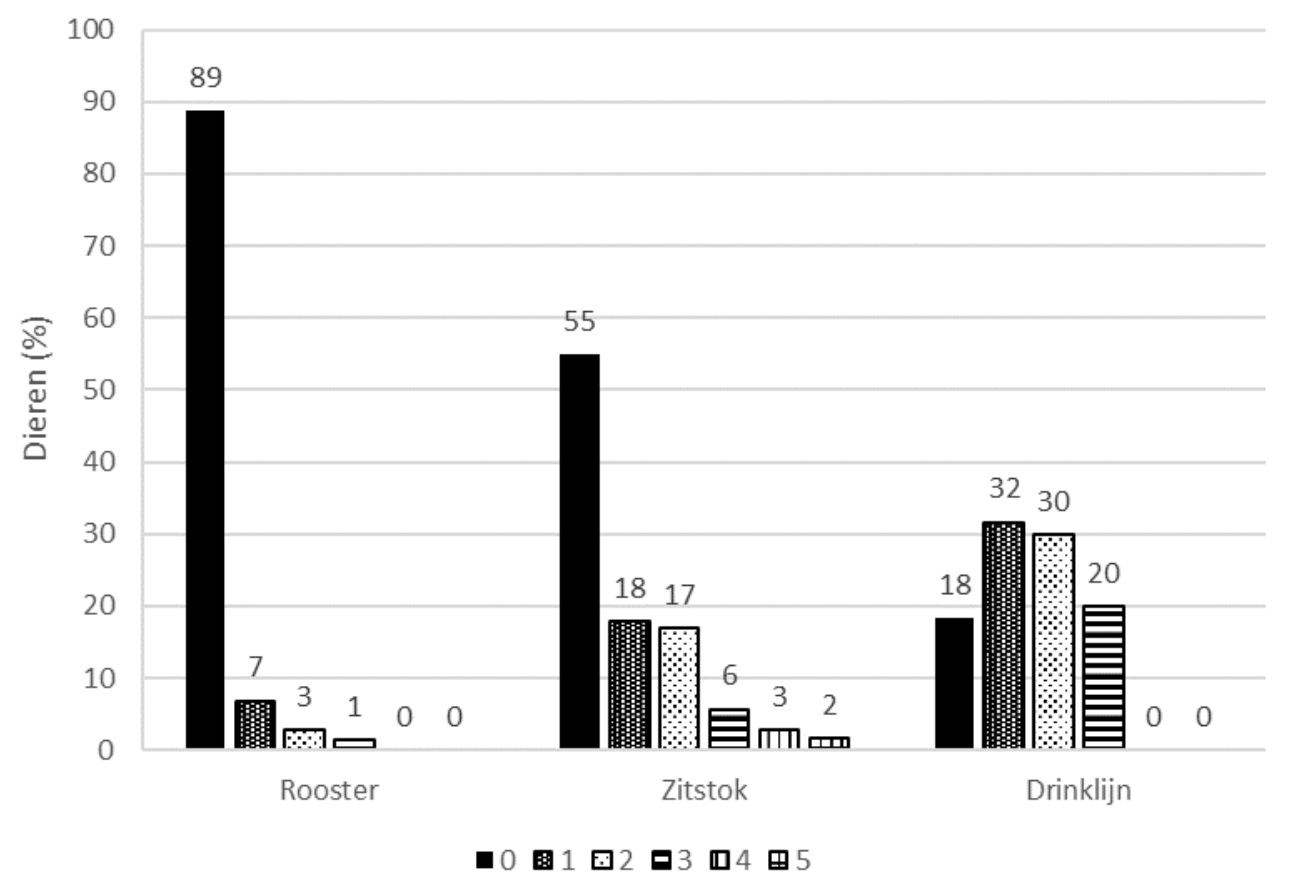

Figuur 5 Ernst borstblaren bij gemerkte dieren (\%) bij de verschillende rustplaatsen.

De waarnemingen naar de prevalentie van borstblaren op 55 en 59 weken leeftijd aan de dieren tijdens de donkerperiode, lieten een iets ander niveau bij met name het rooster en de zitstokken zien (Tabel 5). De verdeling was echter hetzelfde: de hoogste prevalentie aan borstblaren bij de dieren op de drinklijn en de laagste prevalentie bij de dieren op het rooster, terwijl de dieren op de zitstokken er tussen in zaten. Het percentage dieren waarbij een borstblaar is geobserveerd op het rooster en zitstokken was echter hoger bij deze waarnemingen t.o.v. de waarnemingen aan de gemerkte dieren. Waarschijnlijk komt dit doordat de waarnemingen in de donkerperiode zijn gedaan bij random dieren die op moment van beoordelen zich daadwerkelijk op een bepaald rustplaats bevonden. Bij de random dieren was het niet bekend of de dieren regelmatig op die betreffende rustplaats verbleven of toevallig daar tijdens de beoordeling verbleven of misschien naar het rooster waren gegaan omdat ze borstblaren hadden. Bij de gemerkte dieren was bekend hoe vaak de dieren op de betreffende rustplaats verbleven in de voorperiode voor de beoordeling.

Tabel 5 Prevalentie van borstblaren (\% dieren) in de tijd van random dieren op de verschillende rustplaatsen.

\begin{tabular}{lccccc}
$\begin{array}{l}\text { Leeftijd } \\
\text { (weken) }\end{array}$ & Rooster & Zitstokken & Drinklijn & SEM & P-waarde \\
55 & $39,2^{\mathrm{c}}$ & $64,0^{\mathrm{b}}$ & $74,2^{\mathrm{a}}$ & 4.3 & $<0,001$ \\
\hline 59 & $52,2^{\mathrm{c}}$ & $79,4^{\mathrm{b}}$ & $92,8^{\mathrm{a}}$ & 3.8 & $<0,001$ \\
\hline $\begin{array}{l}\text { Gemiddeld } \\
\text { a-c Verschillende letters in dezelfde rij geven een verschil aan }(P<0,05) .\end{array}$ & $83,7^{\mathrm{a}}$ & 2.9 & $<0,001$ \\
\hline
\end{tabular}

Er was een vergelijkbare verdeling in grootte en ernst van de borstblaren bij de waarnemingen aan de random dieren op de verschillend rustplaatsen (Figuur 6). De dieren op de zitstokken en drinklijn hadden t.o.v. de dieren op het rooster grotere borstblaren. De gemiddelde score voor het rooster, de zitstokken en de drinklijn was respectievelijk 0,6, 1,2 en 1,6. 


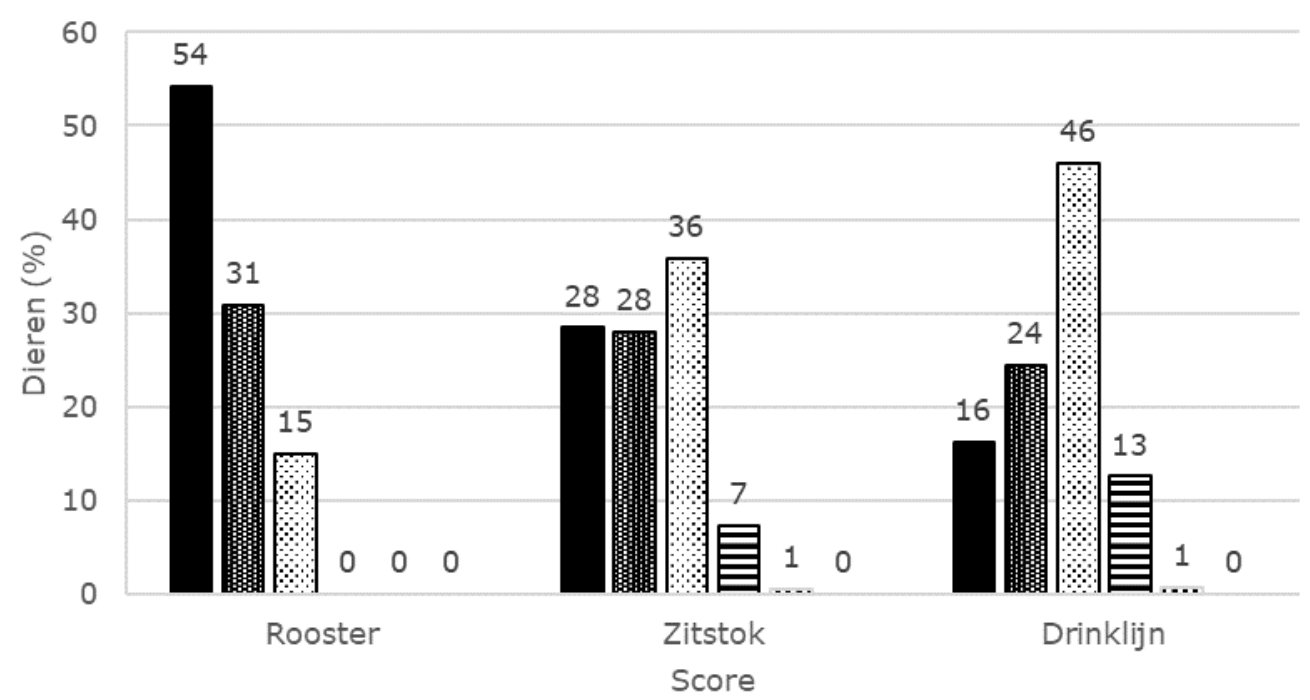

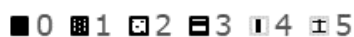

Figuur 6 Ernst borstblaren bij random dieren op de verschillende rustplaatsen.

De hogere prevalentie aan borstblaren bij dieren die op zitstokken rusten gedurende de nacht komt overeen met het Zweedse onderzoek bij praktijkbedrijven (Von Wachenfelt en Berndtson, 2014). Uit dat onderzoek bleek dat relatief veel dieren die gebruik maakten van de zitstokken (ook voer- en waterleiding) enige vorm van schade/afwijking (roodkleuring huid, wonden, blaren, etc.) aan de borst hadden. Op 40 en 58 weken leeftijd was dit bij respectievelijk 78 en $91 \%$ van de dieren het geval. Bij de dieren die op de vloer of op het rooster (tussen de zitstokken) zaten lag dit slechts op respectievelijk 33 en 32\%. In experimenten in Zwitserland (Gebhardt-Henrich et al., 2017, 2018) werd bij gemiddeld $20 \%$ van de dieren die op zitstokken overnachten borstblaren aangetroffen. 


\section{Conclusies}

Uit de preferentietest met verschillende rustplaatsen blijkt dat ouderdieren een duidelijke voorkeur hebben voor een rooster (51,5\% van de dieren) in vergelijking met een zitstok (23,9\% van de dieren) om 's nachts op te rusten. Daarnaast werd bijna $80 \%$ van de dieren in meer dan $75 \%$ van de waarnemingen consistent op hun geprefereerde rustplaats waargenomen. Er werden meer en grotere borstblaren aangetroffen bij de dieren op de zitstokken $(45,0 \%$ van de hennen met gem. score 0,9$)$ en drinklijn $(81,7 \%$ van de hennen met gem. score van 1,9$)$ t.o.v. het rooster $(11,3 \%$ van de hennen met gem. score 0,2$)$. 


\section{Literatuur}

Productschap Pluimvee en Eieren, 2006. Verordening Welzijnsnormen Vleeskuikenouderdieren 2003. Productschap Pluimvee en Eieren, Zoetermeer, Nederland.

Productschap Pluimvee en Eieren, 2010. Verordening Welzijnsnormen Vleeskuikenouderdieren 2003. Productschap Pluimvee en Eieren, Zoetermeer, Nederland.

Brake, J. 1987. Influence of presence of perches during rearing on incidence of floor laying in broiler breeders. Poult. Sci. 66:1587-1589.

Brandes, A., Gierberg M.F., Kemper, N., Spindler, B. 2017. Gegenwärtiger Einsatz von Sitzstangen in der Masthühnerelterntierhaltung sowie deren Eignung hinsichtlich Nutzung und Tiergesundheit (Status quo Erhebung). Institut für Tierhygiene, Tierschutz und Nutztierethologie (ITTN), Stiftung Tierärztliche Hochschule Hannover.

Cordiner, L.S., Savory, C.J., 2001. Use of perches and nest boxes by laying hens in relation to social status, based on examination of consistency of ranking orders and frequency of interaction. Appl. Anim. Behav. Sci. 71, 305-317.

de Jong, I.C., van Wijhe-Kiezebrink, M. 2014. Use of different types of enrichment in slower growing broilers: a pilot study (Report No. 810), Wageningen UR Livestock Research

Gebhardt-Henrich, S.G., Toscano, M.J., Würbel, H. 2017. Perch use by broiler breeders and its implication on health and production. Poult. Sci. 0:1-11.

Gebhardt-Henrich, S.G., Toscano, M.J., Würbel, H. 2018. Use of aerial perches and perches on aviary tiers by broiler breeders. Appl. Anim. Beh. Sci. 203:24-33.

Genstat. 2018. Genstat 19th Reference Manual: Release 1. Clarendon Press, Oxford, UK.

Heikkilä, M., Wichman, A., Gunnarsson, S., Valros, A. 2006. Development of perching behaviour in chicks reared in enriched environment. Appl. Anim. Behav. Sci. 99:145-156.

Malchow, J., Berk, J., Puppe, B., Schrader, L. 2019. Perches or grids? What do rearing chickens differing in growth performance prefer for roosting? Poult. Sci. 98, 29-38.

McCune, E.L., Dellmann, H.D. 1968. Developmental origin and structural characters of "breast blisters" in chickens. Poult. Sci. 47:852-858.

Newberry, R.C., Estevez, I. Keeling, L.J. 2001. Group size and perching behaviour in young domestic fowl. Appl. Anim. Behav. Sci. 73:117-129.

Norring, M., Kaukonen, E., Valros, A. 2016. The use of perches and platforms by broiler chickens. Appl. Anim. Behav. Sci. 184, 91-96.

Oester, H., Wiedmer, H., Witkowski, A. 2005. Evaluation of elevated surfaces and perches for broilers. Proc. 7th Europ. Symp. Poultry Welfare, Lublin, Poland 231-240.

Olsson, I.A., Keeling, L.J. 2000. Night-time roosting in laying hens and the effect of thwarting access to perches. Appl. Anim. Behav. Sci. 68:243-256.

Olsson, I.A.S., Keeling, L.J. 2002. The push-door for measuring motivation in hens: laying hens are motivated to perch at night. Anim. Welf. 11:11-19.

Schrader, L., Müller, B. 2009. Night-time roosting in the domestic fowl - the height matters. Appl. Anim. Behav. Sci. 121:179-183.

van Emous, R.A., Gunnink, H., Binnendijk, G.P. 2018. Het effect van een verhoogde rustplaats op het gebruik en het gedrag bij opfok vleeskuikenouderdieren. Rapport 1047. Wageningen Livestock Research, Wageningen.

von Wachenfelt, E., Berndtson. E. 2014. Usage of perches in meat fowls. Sveriges lantbruksuniversitet Fakulteten för landskapsarkitektur, trädgårds- och växtproduktionsvetenskap. Rapport 2014:3.

Wichman, A., Heikkila, M., Valros, A., Forkman, B., Keeling, L.J. 2007. Perching behaviour in chickens and its relation to spatial ability. Appl. Anim. Behav. Sci. 105:165-179.

Wood-Gush, D.G.M., Duncan, I.J.H., Savory, C.J. 1978. Observations on the social behaviour of domestic fowl in the wild. Bio. of Behav. 3:193-205 


\section{Bijlage 1 Indeling hokken in de voor- en experimentele periode}

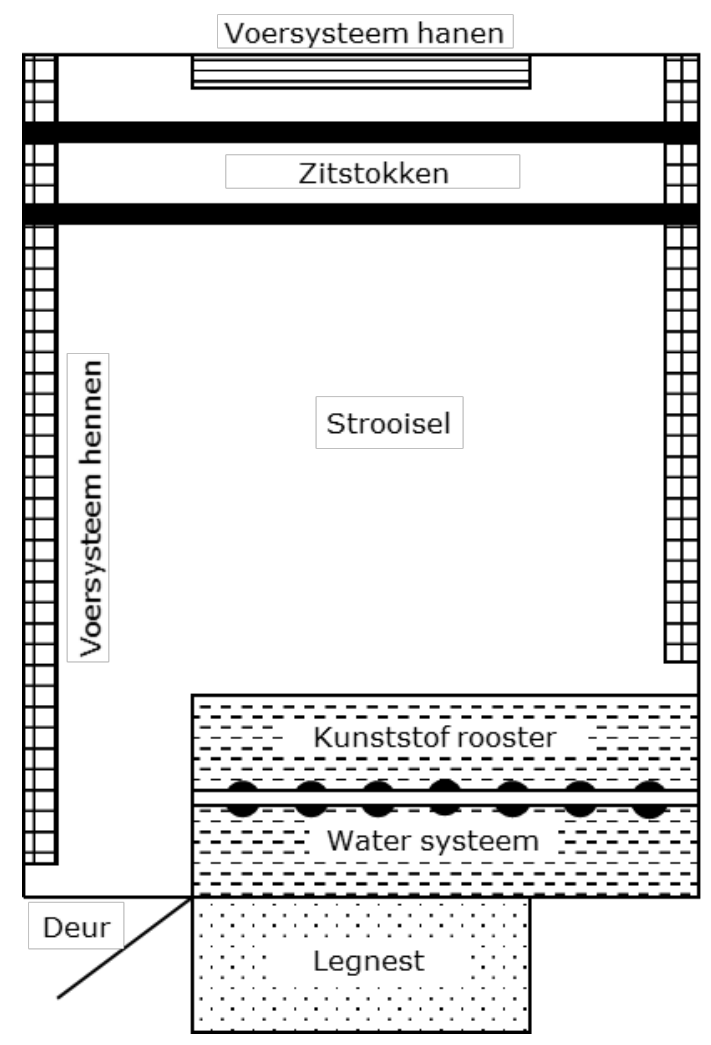

Indeling hokken tussen 6 en 40 weken leeftijd

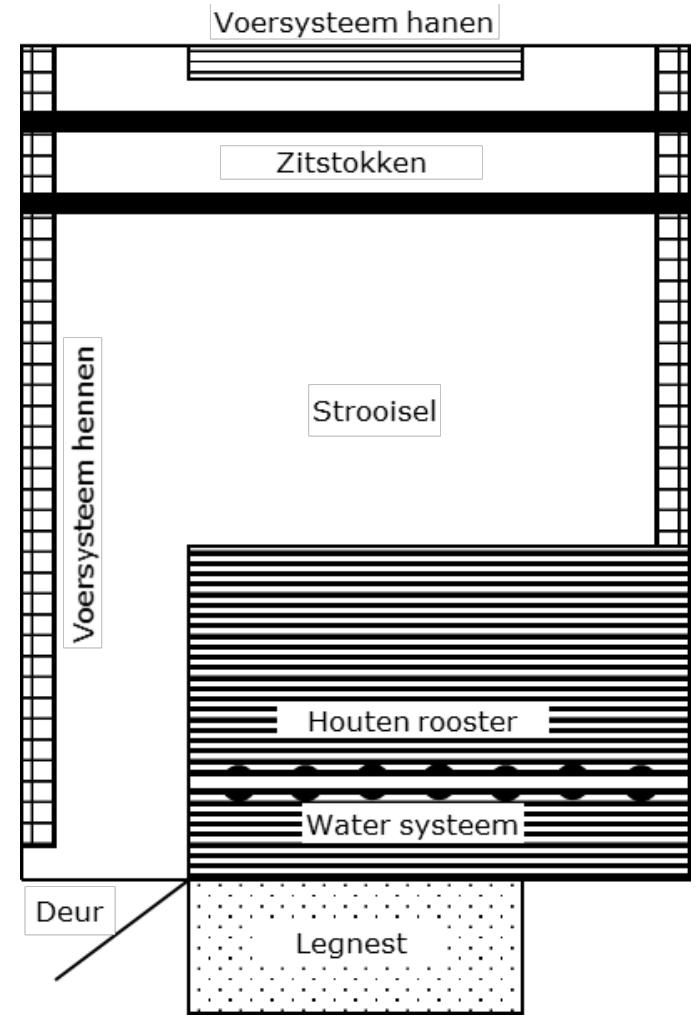

Indeling hokken tussen 40 en 60 weken leeftijd 


\section{Bijlage 2 Verloop van het percentage dieren op of in de verschillende rustplaatsen (incl. voorperiode)}

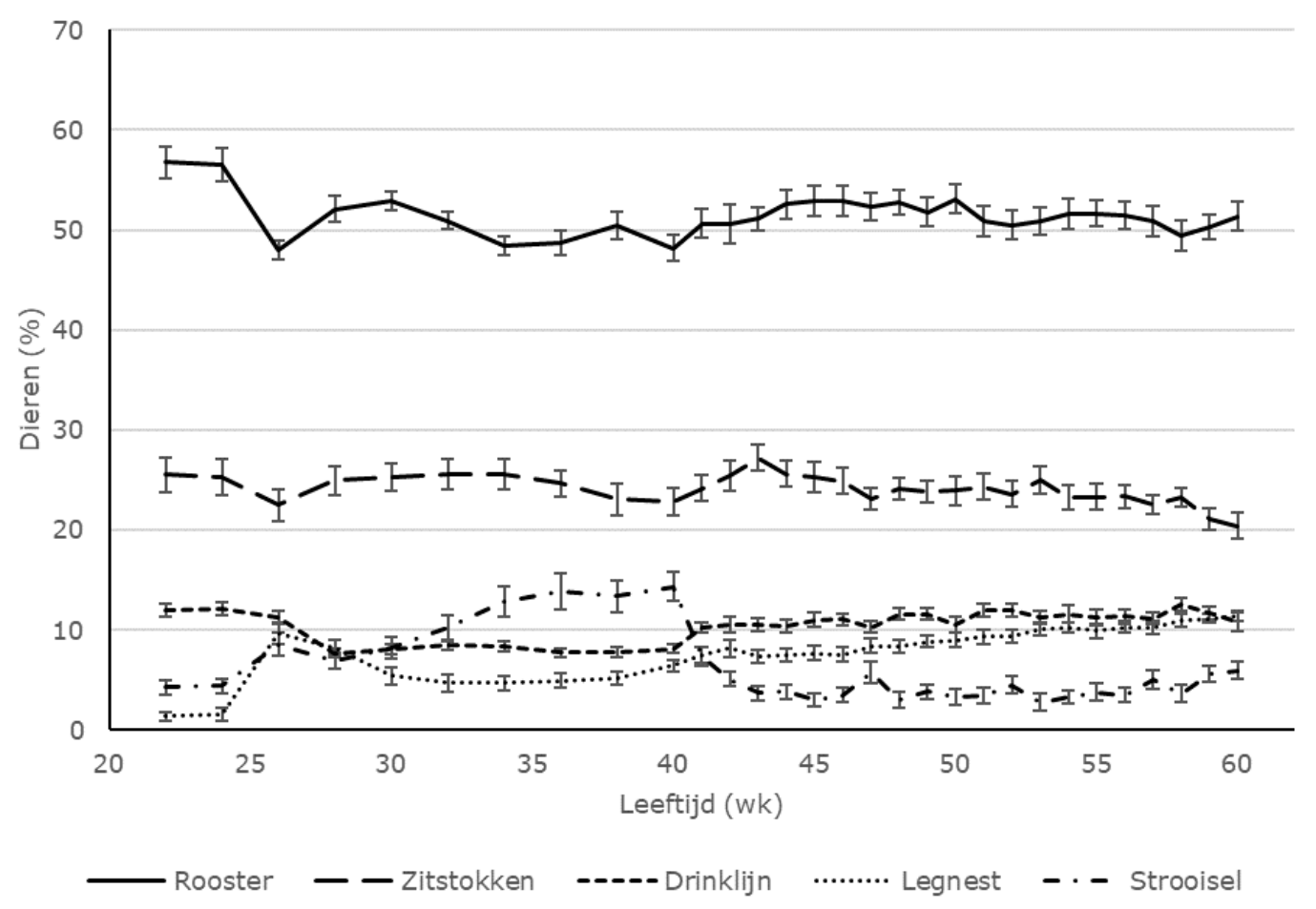




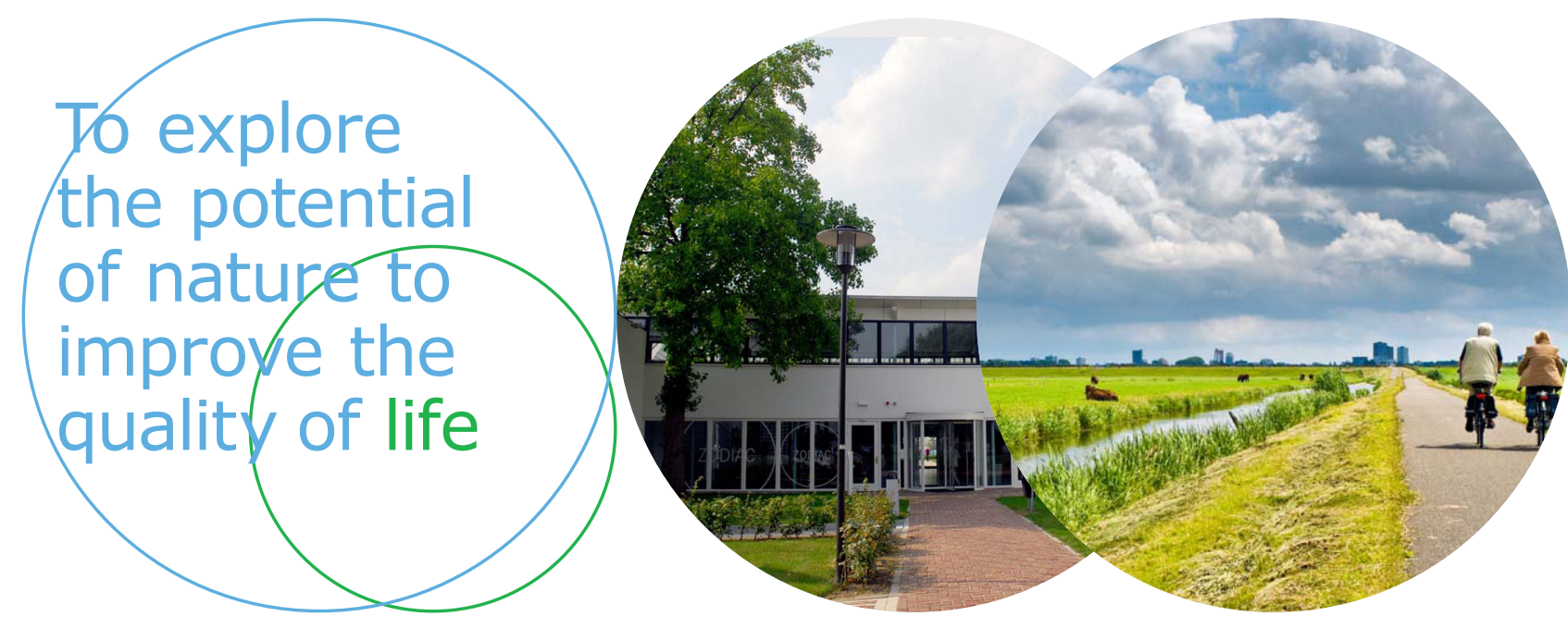

Wageningen Livestock Research Postbus 338

$6700 \mathrm{AH}$ Wageningen

T 0317483953

E info.livestockresearch@wur.nl www.wur.nl/livestock-research
Wageningen Livestock Research ontwikkelt kennis voor een zorgvuldige en renderende veehouderij, vertaalt deze naar praktijkgerichte oplossingen en innovaties, en zorgt voor doorstroming van deze kennis. Onze wetenschappelijke kennis op het gebied van veehouderijsystemen en van voeding, genetica, welzijn en milieu-impact van landbouwhuisdieren integreren we, samen met onze klanten, tot veehouderijconcepten voor de $21 \mathrm{e}$ eeuw.

De missie van Wageningen University \& Research is 'To explore the potential of nature to improve the quality of life'. Binnen Wageningen University \& Research bundelen 9 gespecialiseerde onderzoeksinstituten van Stichting Wageningen Research en Wageningen University hun krachten om bij te dragen aan de oplossing van belangrijke vragen in het domein van gezonde voeding en leefomgeving. Met ongeveer 30 vestigingen, 6.500 medewerkers en 10.000 studenten behoort Wageningen University \& Research wereldwijd tot de aansprekende kennisinstellingen binnen haar domein. De integrale benadering van de vraagstukken en de samenwerking tussen verschillende disciplines vormen het hart van de unieke Wageningen aanpak. 